\title{
KÖNYVTÁROSKÉPZÉS LENGYELORSZÁGBAN: DILEMMÁK ÉS PROBLÉMÁK
}

\section{ELŻBIETA BARBARA ZYBERT}

\section{Tartalmi összefoglaló}

Lengyelországban csak a második világháború után indult meg a felsőfokú könyvtárosképzés (1946) három egyetemen (Łódz, Varsó, Wrocław). Kezdetben csak a tudományos könyvtárak, később a közkönyvtárak számára is képeztek szakembereket. Jelenleg a közel negyvenmilliós országban a 32 ezer könyvtárban több mint ötvenezer munkatárs tevékenykedik (2012.).

A 2012. évi kulturális törvény lehetövé tette, hogy a könyvtárakat összevonják a müvelödési központokkal, klubokkal, múzeumokkal (17,4\%). Az eltérö intézmények és körülmények, a követelmények, továbbá a technológia változásai a könyvtárosok képzésére és továbbképzésére is kihatottak. A Könyvtárfejlesztési Program fontos szerepet játszott a fejlesztések megvalósításában. A jövő szakemberei a szükséges korszerü ismereteket megszerezhetik, ha beiratkoznak a tíz felsőoktatási intézmény valamelyikébe, ha (más szakos diplomásként) posztgraduális kurzusokat látogatnak vagy, ha emelt szintü továbbképzéseket végeznek el. Ezeken a hagyományos tárgyakon kívül az új kompetenciákra felkészítö tárgyak is szerepelnek (információmenedzsment, webes publikálás, közösségi média stb.). Problémát jelent, hogy számos könyvtár alkalmaz könyvtáros végzettséggel nem rendelkező diplomásokat, s egyesek kétségbe vonják a könyvtártudományi tanulmányok szükségességét. Ezt erösítette az ún. deregulációs törvény is, és azt eredményezte, hogy csökkent a könyvtár szak iránt az érdeklödés a felsőoktatásra jelentkezők körében. Tanulmánya végén az ennek ellensúlyozására tett intézkedéseket ismerteti a szerzö.

https://doi.org/10.46280/KOMPKONF.2020.Zybert

\section{Bevezetés}

Lengyelországban a második világháború előtt nem folyt egyetemi könyvtárosképzés; de már a 19. században tartottak Bibliográfia címmel előadásokat a lengyel egyetemeken. Ezeken a kifejezetten bibliográfiai tartalmakon kívül, az írás-, könyv- és könyvtörténet bizonyos aspektusairól esett szó. ${ }^{1}$ Az első könyvtártudományi tanszék a łódzi (1946), majd a varsói (1951) és a wrocławi (1957) egyetemen létesült. Először kétlépcsős képzés indult; az első ciklus végén a hallgatók ún. szakdiplomát kaptak, és csak korlátozott számú hallgató léphetett

\footnotetext{
BIRKENMAJER, A.: Rozwój i stan obecny wyższych studiów bibliotekoznawczych w Polskiej Rzeczypospolitej Ludowej [A Varsói Egyetem Könyvtártudományi Tanszékén dolgozó munkatársak közös munkája. 1957. december. In: Warszawskie uniwersyteckie studia bibliotekoznawcze i informacyjne (1951-2001) Warszawa, 2002. 18. p.
} 
a második ciklusba, melyben mesterfokozatot szerezhettek. A felsőoktatásban tapasztalható létszámhiány következtében a kétlépcsős képzés egyre inkább négyéves mesterképzésre rövidült, melyet 1956-ban ötévessé tettek. ${ }^{2}$ 1964/65 és 1980/81 között ismét négyéves lett a képzés, majd az 1981/82-es tanévben négy és fél éves. 1982/83-tól 1996/97-ig ismét ötéves lett a tanulmányi idő. 2000/2001 óta ismét kétlépcsőssé vált a képzés, külön felvételi eljárással a bachelor- és a mesterfokozat megszerzésére. ${ }^{3}$

Az első három tanszék bölcsész tanszék volt, és az egyetemi struktúrában a polonisztika karhoz tartozott ${ }^{4}$. Idővel azután kialakult a könyvtárosok képzési fokozatainak adminisztratív besorolása. Napjainkban a könyvtártudományi tanszékek már különböző karokhoz tartoznak (nem a polonisztikához): úgymint bölcsésztudományok, történelem, történeti tudományok, vezetés és közösségi kommunikáció, újságírás, információ és könyvtudomány vagy közigazgatás és társadalomtudományok.

Kezdetben a felsőfokú könyvtárosképzés a tudományos könyvtárak jövendő munkatársainak képzését célozta ${ }^{5}$, később azután a közkönyvtárak dolgozóit is oktatták. A későbbiek folyamán a tanulmányok felkészítették a hallgatókat a más könyvtártípusokban végzendő munkákra is azzal a céllal, hogy ki tudják szolgálni a széles olvasóközönség nagyon eltérő csoportjainak az igényeit is.

Egy 2017-es adat szerint Lengyelország népessége 38422 millió fö, vagyis a könyvek és könyvtárak iránt érdeklődő potenciális felhasználók száma igen nagy. A könyvek és könyvtárak minden életkorban (az újszülöttektől a felnőttekig, az idős emberekig és a betegekig) egyformán fontos szerepet játszanak. Lengyelországban 32 ezer könyvtár munkálkodik azon, hogy kielégítse a társadalom különböző igényeit (akikre ügyfélként hivatkoznak). „Hálózatokba szervezik őket a különböző típuson belül jellegük vagy az általuk kiszolgált közönség igényei, gyüjteményük összetétele vagy gyüjtőköre szerint, területi illetékességük, szervezeti és jogi alapjuk, pénzügyi támogatásuk alapján megkülönböztetve, illetve ahogy állományukat hozzáférhetővé teszik"6. Általános feladataikon kívül a könyvtárak nagyon különböznek egymástól. ${ }^{7}$

A Lengyel Statisztikai Hivatal 2012. évi adatai szerint ezen könyvtárak közül

- 8182 közkönyvtár,

- 1087 tudományos könyvtár (tudományterületek könyvtárai, szakkönyvtárak, felsőoktatási intézmények könyvtárai, a tudományos akadémia könyvtárai, kutatóintézetek könyvtárai),

- 318 pedagógiai könyvtár,

- 369 szakkönyvtár,

- 65 szak- és szépirodalmi könyvtár,

2 Uo. 19. p.

3 SOSIŃSKA-KALATA, B.: Programy kształcenia bibliotekoznawczego i informacyjnego w IINiSB UW. In: Warszawskie uniwersyteckie studia bibliotekoznawcze i informacyjne (1951-2001) Warszawa, 2002. 47 p.

4 Kezdetben a lódzi Könyvtártudományi Tanszék a Bölcsészettudományi Karon müködött, majd a Filológiai Kar része lett, annak létrejötte után 1952-ben.

5 BIRKENMAJER, A.: Rozwój i stan ... i. m. 22. p.

6 Stan bibliotek w Polsce. Raport 2012. Libraries in Poland. The 2012 Report. Warszawa, 2016. 98. p.

7 Uo. 98. p. 
- 28 müszaki tudományos és gazdasági központi könyvtár,

- 14 tudományos társaság könyvtára,

- 20363 iskolai könyvtár,

- 1480 egyházi könyvtár és

- 157 börtönkönyvtár8.

A könyvtárak Lengyelországban a kulturális intézmények 84,9\%-át teszik ki; kulturális intézmények továbbá a művelődési központok és klubok, a múzeumok, a színházak és a müvészeti galériák is. Utóbbiak száma is jelentős:

- művelődési központ, napközi ellátást biztosító intézmény és klub: 3870,

- múzeum és múzeum jellegü intézmény: 866,

- színházak és zenei intézmények: 174 ,

- galériák: 344 ,

- mozik: 453.

A kulturális tevékenység végzéséről és szervezéséről szóló törvény ${ }^{10}$, mely 2012 októberében lépett hatályba, lehetővé tette a könyvtárak más kulturális intézményekkel való összevonását, elsősorban a művelődési központokkal és klubokkal, napközi ellátást biztosító intézményekkel, múzeumokkal és múzeum jellegü létesítményekkel. 2012-ben a könyvtárak és fiókjaik közel egyötöde (17,4\%) olvadt össze más intézménnyel (8,2\% városi és 22,2 vidéki településeken), többnyire a művelődési központtal vagy egyéb kulturális intézménnyel ${ }^{11}$.

Így számos olyan könyvtárunk lett, melyek feladatai, szerepe, funkciói és célcsoportjai eltérnek egymástól, és egyedi, hozzájuk igazított munkamódszereket és tevékenységi formákat igényelnek.

2012-ben körülbelül 54626 könyvtáros dolgozott Lengyelországban a következő bontásban:

- közkönyvtárakban dolgozott több mint 23,3 ezer fö, köztük közel 18 ezer könyvtá$\operatorname{ros}^{12}$. 2012-ben kétharmaduk (71,5\%) rendelkezett szakképesítéssel, köztük 41,9\% felsőfokú diplomával (köztük olyanok is, akiknek csak bachelor-fokozatuk volt) ${ }^{13}$;

- tudományos könyvtárban dolgozott 11 ezernél több fö, köztük több mint 86\% könyvtárosként. „E csoport fontos jellemzője, hogy ők jól felkészült szakemberek - a tudományos könyvtárak munkatársainak 58\%-a rendelkezik felsőfokú könyvtáros végzettséggel. A tudományos könyvtárakra az a jellemző, hogy olyan

10 Act on Organising and Running Cultural Activities. Journal of Laws of the Republic of Poland of 2012. A 406. tétel a módosítás szerint.

11 Stan bibliotek w Polsce ... i. m. 17. p.

12 Uo. 102.p.

13 Uo. 103. p. 
szakterület szakértőit alkalmazzák, amilyen témára az adott könyvtár gyüjteménye szakosodott ${ }^{14}$;

- pedagógiai könyvtárban dolgozott 2289 fö, ebből 1593 könyvtári szolgáltatást végzett, s 97,8\% rendelkezett egyetemi könyvtáros diplomával ${ }^{15}$;

- szakkönyvtárban 1010 fö dolgozott, ebböl 896 (88,7\%) könyvtárosként ${ }^{16}$;

- szak- és szépirodalmi könyvtárban 129 fö dolgozott, 85\%-uk foglalkozott könyvtári teendőkkel ${ }^{17}$;

- műszaki tudományos és gazdasági központok könyvtáraiban 47 fö dolgozott öszszesen, valamennyien könyvtárosként ${ }^{18}$;

- a tudományos társaságok könyvtárai 17 föt foglalkoztattak ${ }^{19}$;

- iskolai könyvtárakban közel 22,3 ezer fö dolgozott (17 014 könyvtárostanár és 5270 tanár, akik nem föfoglalkozásúként dolgoztak a könyvtárban, de kötelesek voltak heti egy órában az iskolai könyvtárban szolgálatot ellátni) ${ }^{20}$.

Világos, hogy a könyvtárakban dolgozóknak különböző képzettségre van szükségük ahhoz, hogy könyvtárosként dolgozhassanak, egyrészt egy speciális terület ismeretére (a könyvtár típusának megfelelően), másrészt könyvtári gyakorlatra, amennyiben a dokumentumok gyarapításáról, feldolgozásáról és megosztásáról, az olvasókkal és az információs forrásokkal való foglalkozásról, a munka megszervezéséről, könyvtárvezetésről, marketingről vagy reklámról van szó, hogy csak néhány tevékenységet említsünk.

Az egyik fontos tényező, amely kihat a könyvtári szolgáltatások színvonalára, az a könyvtárosok szakmai készségeinek folyamatos fejlesztése és javítása. Az elmúlt két évtizedben fontos erőfeszítések történtek a könyvtárosok szakmai kompetenciáinak emelésére, nemcsak olyan workshopok rendezésével, melyek haladó számítógépes és IT-használati képességeket kívántak meg, hanem olyanokéval is, melyek a könyvtárosok képességeit és tudását igazították hozzá az új kulturális és társadalmi igényekhez. „A Könyvtárfejlesztési Program (melyet az Információs Társadalom Fejlesztési Alapítvány vezetett) fontos szerepet játszott az elmúlt néhány évben; a Lengyel Nemzeti Könyvtár és a Lengyel Könyvtárosok Egyesülete is számos lehetőséget biztosított a könyvtárosoknak, hogy fejlesszék szakmai készségeiket”21.

Feladataik elvégzéséhez a jövő könyvtárosai úgy szerezhetik meg a szükséges képzettséget,

- ha beiratkoznak egyetemre, és BA- és MA-fokozatot szereznek; 
- ha posztgraduális kurzusokat végeznek el (melyeket főleg olyan nem könyvtár szakot végzett diplomások számára alakítottak ki, akik új képzettséget is szeretnének szerezni);

- ha emelt szintü továbbképzéseken vesznek részt, melyek a könyvtáros egyesület, a nemzeti könyvtár és a különböző hálózatok könyvtárai által szervezett különböző tanfolyamok és workshopok keretében folynak.

Jelenleg egyetemi könyvtár- és információtudományi képzés (BA és MA szinten) tíz felsőoktatási intézményben folyik Lengyelországban:

- Bydgoszcz: Uniwersytet Kazimierz Wielki (UKW) Közigazgatási és Társadalomtudományi Kar, Információ- és Könyvtudományi Tanszék;

- Katowice: Uniwersytet Śląski (UŚ) Filológiai Kar, Információ- és Könyvtártudományi Intézet;

- Kraków: Uniwersytet Jagielloński (UJ) Menedzsment és Közösségi Kommunikáció Kar, Információ- és Könyvtártudományi Intézet;

- Kraków: Uniwersytet Pedagogiczny (UP) Filológiai Kar, Információtudományi Intézet;

- Kielce: Uniwersytet Jana Kochanowskiego (UJK) Bölcsészettudományi Kar, Újságírás és Információ Intézet;

- Lublin: Uniwersytet Marii Curie-Skłodowskiej (UMCS) Bölcsészettudományi Kar, Tudományos Információ és Könyvtártudományi Intézet;

- Łódz: Uniwersytet Łódzki (UL) Filológiai Kar, Könyvtár- és Információtudományi Tanszék;

- Toruń: Uniwersytet Mikołaja Kopernika (UMK) Történettudományi Kar, Információtudományi és Könyvtanulmányok Intézet;

- Warszawa: Uniwersytet Warszawski (UW) Újságírás Kar, Információ és Könyvtanulmányok;

- Wroclaw: Uniwersytet Wrocławski (UWr) Filológiai Kar, Könyvtár- és Információtudományi Intézet.

Ezeken a tanszékeken különféle bachelor-fokozatok megszerzésére van lehetőség. Az oktatói kartól függően egynél több féle fokozat szerezhető a fenti intézetekben. Az alábbi egyetemek kínálnak BA fokozatot:

- könyvtár- és információtudomány: UW, UP, US, UJ, UKW, UMK;

- információmenedzsment: UJ;

- információ digitális környezetben: UL;

- információ az e-társadalom intézményeiben: US;

- információs architektúra: UP, UMCS, UMK;

- modern kiadás: UW;

- webes publikálás: UWr;

- információmenedzsment és könyvtártudomány: UJK (a szak nem indult az 2017/18. tanévben). 
Nem minden egyetemen lehet mester-fokozatot szerezni könyvtártudományból. Ahol igen, azok az alábbiakat kínálják:

- könyvtár- és információtudomány: UW, UP, UWr, US, UJK, UMK, UL;

- alkalmazott információtudomány: UMCS;

- információmenedzsment: UJ;

- információmenedzsment és digitális publikálás: UP;

- információmenedzsment és könyvtanulmányok: UMK.

Az alábbi szakirányok érhetők el a mesterképzés keretében könyvtár- és információtudományból:

- iskolai könyvtárak;

- köz- és iskolai könyvtárak;

- könyvtárak a tudásalapú társadalomban;

- a sajtó a társadalom kommunikációs rendszerében;

- könyvtárak vezetése és szervezése;

- digitális könyvtárak és az információmenedzsment;

- kiadványszerkesztés;

- könyvtörténet;

- digitális könyvtárak és az internet;

- a kulturális örökséget gondozó intézmények (a történeti gyűijteményekkel foglalkozók számára).

Minden lengyel egyetemen, ahol könyvtár- és információtudományi képzés folyik, különböző posztgraduális programok is vannak azok számára, akik már rendelkeznek valamilyen alapképzésben szerzett végzettséggel. A programok a következők: könyvtár- és információtudomány, információs architektúra, biblioterápia, kiadványszerkesztés, kulturális intézmények vezetése, információbrókerség és kultúramenedzsment, webes publikálás, kiadáspolitika és könyvértékesítés, az új média információs technológiái, a kultúra és közigazgatás új technológiái és a digitális gyüjtemények építése.

Számos ilyen kurzus van, és igen eltérő tanmeneteik vannak. Néhány közülük nem indul minden évben a jelentkezők alacsony száma miatt.

A könyvtárak és más kulturális intézmények jövőbeli munkatársainak felsőoktatási képzési lehetőségei bőségesnek látszanak, és alkalmasak arra, hogy e munkatársak növelni tudják képzettségüket és a szükséges mértékben ki tudják bővíteni mind az ismereteiket, mind a kompetenciáikat annak érdekében, hogy meg tudjanak felelni a használók megnövekedett igényeinek és elvárásainak.

Az említett könyvtár- és információtudományi központokon kívül léteznek posztgraduális programok olyan felsőoktatási intézményekben és karokon is, ahol nem folyik könyvtárosképzés, pl. a Wyższa Szkoła Bankowaban Gdańskban és Chorzów/Katowicében vagy a lódzi Egészségnevelési és Társadalomtudományi Főiskolán. Ez versenyhelyzet, amely nem mindig fair, de folyamatosan új diákok megszerzésére ösztönöz, és nem feltétlenül kedvez 
annak, hogy valaki könyvtár- és információtudományi képzést tartson fenn vagy fejlesszen. Amint a fentiekben látható volt, Lengyelországban sok könyvtár müködik, ezekben több tízezren dolgoznak, és vibráló munkaerőpiacot kínálnak egyre több új álláshellyel.

Problémát jelent az a tény, és jelentősen befolyásolja a könyvtárosok képzését és az elvárásokat, hogy egyre több könyvtár alkalmaz olyan nem könyvtáros diplomásokat, akik nem találtak munkát a maguk szakterületén. Főleg ezekben a közösségekben fordul elő, hogy kétségbe vonják a könyvtártudományi tanulmányok szükségességét. Azt állítják, hogy a könyvtártudomány tanulása során a hallgatók nem tesznek szert elegendő tudásra, mivelhogy a munkaerőpiac valósága túl gyorsan fejlődik.

M. Szablewski és W. Zakrzewiski ${ }^{22}$ Ryan Deschampsra hivatkozva (Ten reasons why „professional librarian" is an oxymoron) azt ismételgetik, hogy a professzionális könyvtáros, azaz aki egyetemi fokozatot szerzett könyvtár- és információtudományból, oximoron: olyan retorikai alakzat, amely látszólag egymást kizáró, egymásnak ellentmondó fogalmakat tartalmaz. Öt idézve hozzáteszik, hogy „A szakma valósága, formátumai és a munkanormák gyors változásnak vannak kitéve, míg a könyvtár munkatársai olyan sokféle feladatot teljesitenek számos tudásterület eredményeinek felhasználásával, hogy a könyvtártudományi tanulmányok nem készitik fel őket, de nem is tudnának senkit sem felkészíteni a könyvtárban való munkára" ${ }^{23} \mathrm{Az}$ ilyen kijelentések szerzői - úgy tünik - elhanyagolják azt a tényt, hogy a folyamatos fejlesztés és a különféle érdekek fenntartása minden szakmában, és az emberi tevékenység bármely területén létfontosságú ahhoz, hogy feladatait bárki hatékonyan és kielégítő módon végezze el. Az oktatás során megszerzett tudás sosem lesz elég az egész szakmai pályafutásra.

Amikor megkérdőjelezik a könyvtári munka professzionálissá válását, azt hangsúlyozzák, hogy ma a könyvtárosok által végzett sokféle feladat és a felhasználók változó igényei miatt a könyvtári munkatársak oktatási hátterét diverzifikálni kell24 ${ }^{24}$

M. Szablewski és W. Zakrzewiski, számos olyan híres könyvtáros példáját említik, akik nem könyvtártudományi, hanem más tanulmányokat folytattak (így a MARC formátumot kifejlesztő matematikus Henriett Avramét és Arro Smithét, aki filozófiából és vallástudományokból szerzett diplomát), úgy vélik, hogy a könyvtáros szakmát nem lenne szabad monopolizálniuk (ahogy ők fogalmaznak) „a való világban nem létező - bár létrejönni próbáló - professzionális könyvtárosoknak"25, és nyitottnak kellene maradni a más végzettségüekkel szemben, akik szívesen dolgoznának könyvtárban.

Az egyes szakmák gyakorlatát szabályozó törvények módositásáról szóló törvény (röviden: a Deregulációs törvény) ösztönzi a hasonló vitákat ${ }^{26}$, mivel célja a szabályozott szakmákhoz való hozzáférés megkönnyítése a korábbi követelmények (pl. szakmai bizonyítványok vagy engedélyek beszerzésének) csökkentésével vagy eltörlésével, ami - többek között - a

22 SZABLEWSKI, M. - ZAKRZEWSKI, W.: Bibliotekarze XXI wieku: usługodawcy, radykalni katalogerzy i animatorzy kultury. Rocznik

Biblioteki Narodowej vol. XLI, Warszawa, 2015. 345. p.

23 Uo. 345. p.

24 U. 350. p.

25 Uo. 345., 346. p.

26 Act Amending the Laws Regulating the Practice of Certain Professions. Journal of Laws of the Republic of Poland of 2013. 829. tétel. 
könyvtárosokat is érinti. Bár elöször a deregulációra vonatkozó rendelkezések csak az ún. „minősített könyvtárosok” szűk csoportját érintette volna, akik ezt a címet az állami bizottság elött számos szakvizsga letételével szerezték meg, a törvény következményei hatással voltak a teljes könyvtáros szakmára és a képzési folyamatra.

Jelenleg nem szükséges könyvtár szakos diploma vagy posztgraduális fokozat ahhoz, hogy valaki könyvtárosként dolgozhasson valamelyik könyvtárban. A felvételről az egyes könyvtárak vezetése dönt, és választásukat nem mindig indokolja a feladat jellege. Figyelemre méltó azonban, hogy a könyvtudományi tanulmányok elvégzése a hallgatók számára olyan sokrétű tudást biztosít, amely minden könyvtáros számára nélkülözhetetlen. A hallgatók nemcsak a könyv, a nyomdászat és az írás történetéről, hanem az állományépítésről, feldolgozásról és megosztásról, továbbá az olvasókkal való bánásmódról is tanulnak, és foglalkoznak a tudományos információk kérdéseivel, megismerkednek a könyvtári rendszerekkel, szakmájukat átfogó módon sajátítják el. Ezért felkészültek a feladataik ellátására ${ }^{27}$, ismerik részletkérdéseit, míg a nem könyvtár szakot végzett diplomásoknak el kell sajátítaniuk a könyvtári munka alapjait.

Míg egy nem könyvtár szakos diplomás könnyen kap munkát egy könyvtárban, csökkent az érdeklődés a könyvtártudományi szak iránt. Mivel a lengyelországi egyetemek felvételi vizsgáit már évek óta felváltotta a középiskolai érettségi bizonyítványok versenye, a jelentkezők többféle tanulmányi programra is jelentkezhetnek. Ha nem sikerül az elsőnek választott szakra bekerülni, néha úgy döntenek, hogy könyvtártudományt tanulnak, ahol a követelmények kevésbé szigorúak, majd az első tanulmányi év alatt vagy után leadják, és egy másik szakot vesznek fel. Ily módon elfoglalják azok helyét, akik viszont tényleg könyvtár szakosok akartak volna lenni. Figyelembe véve a felvételi keretszámokat és azt a tényt, hogy nem lehet befogadni az összes érdeklődő jelentkező diákot, a valóban könyvtártudományt tanulni akarók gyakran nem kerülnek be a felsőoktatásba. Ezért erőfeszítéseket tesznek a tantervek módosítására és azok tartalmának aktualizálására annak érdekében, hogy vonzóbbá tegyék sok jelentkező számára, hogy a könyvtártudomány legyen az első szak, amelyet megjelölnek.

Hogy vonzóbbá tegyék a szakot, ötletek születtek, hogy a) átnevezzék anélkül, hogy jelentősen megváltoztatnák a tartalmát, vagy b) más oklevél is szerezhető legyen a könyvtár- és információtudományi mellett (pl. információ-építész, kiadványszerkesztő vagy digitális kiadó.)

Amint említettük, az ilyen új végzettségüek száma egyre nő. A tanulmányok tartalma többnyire nem kapcsolódik szigorúan a könyvtártudományhoz, és nem készít fel a könyvtári munkára sem. A végzett diplomás tudna könyvtárban dolgozni, de ez nem kötelező számára, mint a nem könyvtár szakot végzett diplomások esetében sem. Minden egyes felsőoktatási intézményben a felvettek korlátozott száma és ama követelmény miatt, hogy az egyetemi oktatónak legfeljebb két szakterülethez lehet kapcsolódnia, az újonnan bevezetett, vonzóbb nevű képesítések a hagyományos könyvtudományi tanulmányok versenytársaivá váltak.

27 Bibliotekarz - wszystko co warto wiedzieć o pracy w bibliotece. Forrás: https://poradnikpracownika.pl/-bibliotekarz-ile-zarabia-ijak-nim-zostac [2018. október 31.] 
Jelenleg azok a nem könyvtár szakot végzett a diplomások, akik könyvtárban dolgoznak, megszerezhetik azokat a kompetenciákat, amelyekre szükségük van feladataik hatékony ellátásához egy adott könyvtárban, képzett és tapasztalt könyvtárosok által szervezett gyakorlati, munkahelyi képzéseken. Ez azonban néhány év alatt megváltozhat, hiszen az ilyen képzett és tapasztalt könyvtárosok hamarosan nyugdíjba vonulnak egy olyan környezetben, ahol egyre kevesebb a hagyományos könyvtudományi oktatást nyújtó iskolák száma.

Nehéz előre látni, milyen is lesz a könyvtárosképzés a jövőben. Vajon a könyvtártudományi szak - amely a szakmai alapokat oktatja - túléli ezt, vagy az ilyen típusú oktatással ellentétes hangok kerekednek felül?

Az ilyen kérdések megválaszolására szakértői csoportot hoztak létre, hogy írja le a könyvtárosoktól elvárt képzettséget, valamint határozza meg a különböző típusú könyvtárak személyzetétől elvárt ismereteiket, készségeket és szociális kompetenciákat, függetlenül attól, hogy milyen oktatásban vettek részt. Ez a 15 lengyel szakértőből álló csapat 2014 szeptemberében jött létre az Oktatási Kutatóintézetben a Lengyel Nemzeti Könyvtárral együttmüködésben.

Tevékenységük középpontjában az az az elképzelés állt, hogy el kell hagyni a hagyományos formális képzés koncepcióját, amely az előre meghatározott tudás megszerzésén alapul, és azokra a készségekre kell összpontosítani, amelyeket úgy határoztak meg, hogy „képesek a tanulási vagy a szakmai tevékenység területére jellemző feladatokat elvégezni és a problémákat megoldani." ${ }^{28}$ A „könyvtáros” alapképesítést részletesen leírták, és kiegészítették a köz-, iskolai és tudományos könyvtárakban dolgozó könyvtárosoktól elvárt részletesebb képesítési elemekkel. Az utóbbiaknál a szaktájékoztató és a különgyüjteményekért felelős könyvtáros esetét szerepeltették.

Az így létrejött „könyvtáros” szakképzettség leírása hat képzési területből áll (dokumentumok gyüjtése, rögzítése és kiválasztása; dokumentumok formai és tartalmi feltárása; gyüjtemények megosztása; a könyvtári anyagok kezelése és védelme; tájékoztató tevékenység könyvtári módszerekkel és az információs források alapján; felkészítés a könyvtár vezetésére), az értékelés módszereivel egyetemben, ami alapot teremt további korszerü, a tudományos, köz- és iskolai könyvtárak számára nélkülözhetetlen kompetenciák megszerzéséhez ${ }^{29}$.

A szakértői csoport megállapításai szerint „egy könyvtáros alapképzettséggel rendelkező egyén készen áll arra, hogy egy könyvtárban dolgozzon, valamint hogy önállóan müködtessen egy könyvtárat. A könyvtáros összegyüjti, kiválasztja, rögzíti és leírja az állományt mind formai, mind tartalmi szempontból, előkészíti a forrásokat a megosztáshoz és megosztja őket, valamint kezeli és megörzi az állományt. A könyvtáros felelös azért is, hogy tájékoztatást nyújtson a könyvtárhasználók számára. Az ilyen képesitéssel rendelkező egyén jelentősen hozzájárulhat könyvtár menedzselésének folyamatához mások támogatásával” 30 . A képesítés megszerzéséhez a pályázóknak legalább egy éves tapasztalattal kell rendelkezniük a

28 SZABLEWSKI, M. - ZAKRZEWSKI, W.: Bibliotekarze XXI ... i. m. 351. p.

29 Un. 351-353. p.

30 Un. 352-353. p. 
könyvtárban való munkavégzésben, bachelor- vagy annak megfelelő fokozattal kell rendelkezniük, továbbá megfelelő számítógépes ismeretekkel, különösen az irodai szoftverek és az adatbázis-eszközök használatával kapcsolatban, valamint ismerniük kell az információk keresésének, feldolgozásának és megosztásának módszereit különböző hordozók esetén. A társadalmi kompetenciák közül a részletek iránti figyelmet, a megbízhatóságot, a kommunikációs készségeket, a türelmet és az innovatív szellemet említették ${ }^{31}$.

A közkönyvtárak munkatársainál, mivel ők a helyi közösséget alakítják, azt emelték ki, hogy az alapvető képesítéseken kívül olyan kompetenciákkal kell rendelkezniük, hogy tanácskozásokat és a gyermekek számára szóló rendezvényeket szervezzenek az olvasás népszerüsítése és az oktatás támogatása érdekében, valamint olyan szervezési készségekkel, hogy előkészítsenek különböző kulturális eseményeket és tevékenységeket, amelyek a helyi közösségeket segítik igényeik és elvárásaik kielégítésében ${ }^{32}$.

Az iskolai könyvtárosoknak - akiknek a fö feladata az oktatási folyamat támogatása, a tanulók érdeklődésének fejlesztése és a tanárokkal való együttműködés - az alapképesítések és a gyermekeknek és fiataloknak szóló, valamint a pedagógiai irodalom mellett ismerniük kell a pedagógia és a pszichológia alapjait, az olvasókkal való együttműködés módszereit, és demonstrálniuk kell tanulmányaik további eredményeit: hogy képesek oktatási tevékenységet folytatni és az iskola küldetését és céljait kiteljesíteni ${ }^{33}$.

A tudományos könyvtárak esetében az egyetlen „tudományos könyvtáros” kategóriájából kettő lett, a „szakreferens könyvtáros” és a „különgyüjteményekért felelős könyvtáros”. Mivel a szakreferens könyvtárosok többnyire egyetemi oktatók és hallgatók számára szolgáltatnak, egy adott tudományágra kell specializálódniuk a könyvtár profiljának megfelelően, ismerniük kell annak közelmúltbeli irodalmát, és legalább a kutatási módszertan alapjait. A szakértők egyetértettek abban, hogy ilyen képesítés csak azoknak áll rendelkezésükre, akik mesterfokozattal vagy az azzal egyenértékü diplomával bírnak, és akiknek C1 szintü angol és egy második, B2 szintü nyelvvizsgájuk is van. Kiemelték, hogy e csoport könyvtárosainak olyan készségekre van szükségük, amelyek lehetővé teszik számukra, hogy egy-egy tudományág könyvtárát működtetni tudják, ami együttműködést igényel a kutatói közösséggel a források beszerzése, a bibliográfiai összefoglalók készítése, az információs tevékenységek végzése és az információhasználók oktatása területén.

A „különgyüjteményekért felelös könyvtáros” képesítés a szakkönyvtárostól elvártakon kívül magában foglalja a mesterfokozat vagy azzal egyenértékủ diploma követelményét, és a nyelvtudás mellett a történelem, a művészettörténet vagy a zenetudomány szakismeretét is a speciális gyüjteményekkel való munkához. Esetükben legalább két éves könyvtári gyakorlatot írnak elö ${ }^{34}$.

31 Uo. 352-353. p.

32 Uo. 353. p.

33 Uo. 355. p.

34 Uo. 356-357. p. 
A „digitális könyvtáros” kategóriát kizárták az általános könyvtáros minősítésből, és külön definiálták, mivel ez a munka nagyon más, és eltérő terminológiát igényel. A „digitális könyvtáros" végzettség azonban nem követeli meg, hogy a jelölt rendelkezzen a „könyvtáros” számára előírt összes készséggel. Ehelyett főiskolai végzettséggel, vagy azzal egyenértékủ diplomával kell rendelkezniük, és haladó szintű készségekkel kell rendelkezniük az IKT-eszközök használatában, és legalább egy éves tapasztalattal kell rendelkezniük a gyűjtemények digitalizálásával, megosztásával, terjesztésével és archiválásával kapcsolatos feladatok terén ${ }^{35}$.

A lengyel könyvtárak több mint 50000 munkahelyet kínálnak a könyvtárosok számára. A munkaerőpiac kezelése jelentős kihívást jelent. Ez annak a ténynek köszönhető, hogy a könyvtudományi tanulmányok népszerüsége csökkent ugyan, de a könyvtárak továbbra is léteznek, és alkalmaznak új munkatársakat.

Reméljük, hogy mind a könyvtárosok, mind a könyvtárosokat oktató intézmények széles körü egyetértést érnek el az elvárható képesítésekröl és az oktatás hátteréről, hogy mind a jelenlegi, mind a jövőbeli szakemberek megfeleljenek a felhasználók változó igényeinek, valamint hogy vonzzák azokat is, akik még nem kezdték el használni a könyvtári szolgáltatásokat.

\section{Irodalom}

Bibliotekarz - wszystko co warto wiedzieć o pracy w bibliotece. (2017). Forrás: https://poradnikpracownika.pl/-bibliotekarz-ile-zarabia-i-jak-nim-zostac [2018. október 31.]

BIRKENMAJER, Aleksander (2002): Rozwój i stan obecny wyższych studiów bibliotekoznawczych w Polskiej Rzeczypospolitej Ludowej. Warszawa, December 1957. In: Warszawskie uniwersyteckie studia bibliotekoznawcze i informacyjne (1951-2001). Warszawa, ISBN: 83-904036-7-6

DESCHAMPS, Ryan (2010): Ten reasons why „professional librarian” is an oxymoron. Forrás: http:// otherlibrarian.wordpress.com/2010/04/30/ten-reasons-why-professional-librarian-is-an-oxymoron//, idézve: SZABLEWSKI, Maciej - ZAKRZEWSKI, Witold:. Bibliotekarze XXI wieku: usługodawcy, radykalni katalogerzy i animatorzy kultury. vol. XLI, Warszawa, 2011. 341-398. p.

SOSIŃSKA-KALATA, Barbara (2002): Programy kształcenia bibliotekoznawczego i informacyjnego w IINiSB UW. In: Warszawskie uniwersyteckie studia bibliotekoznawcze i informacyjne (1951-2001). Warszawa, ISBN: 83-904036-7-6 43-58. p.

Stan bibliotek w Polsce. Raport 2012. Libraries in Poland. The 2012 Report. (2016). Warszawa, ISBN: 978-83-7009-647-2; ISSN: 2451-0963.

SZABLEWSKi, Maciej - ZAKRZEWSKI, Witold (2015): Bibliotekarze XXI wieku: usługodawcy, radykalni katalogerzy i animatorzy kultury. Rocznik Biblioteki Narodowej. vol. XLI, Warszawa 2015. 341-398. p.

Ustawa o zmianie ustaw regulujących wykonywanie niektórych zawodów. (2013). Dz.U. RP. 829. tétel.

Ustawa o organizowaniu i prowadzaniu działalności kulturalnej. (2012). Dz.U. RP. 406. tétel a módosítás szerint. 
Elzbieta Barbara Zybert a Varsói Egyetem Újságírás, Információ- és Könyvtudományi Karának kinevezett professzora. Felsőoktatási tevékenysége korunk könyvtárügyével kapcsolatos, és föként a következő területekre összpontosít: könyvtári szervezés és menedzsment; a könyvtár szerepe és helye az oktatásban; speciális igényü használók (szellemi fogyatékosok, fizikailag hátrányos helyzetüek, rabok, etnikai kisebbségek stb.). Tudományos érdeklődését jól tükrözi 5 könyve, lengyel és külföldi folyóiratokban megjelent, több mint 90 publikációja. Számos szakkönyv szerkesztője. A Könyvtári és Kulturális Örökség Intézmények Tanszékének vezetője. 2008 és 2018 között az Újságírás, Információ- és Könyvtudományi Kar dékánja; 2005 és 2008 között hallgatói dékánhelyettese volt. Főszerkesztője a legrégibb lengyel könyvtártudományi szakfolyóiratnak (Przegląd Biblioteczny). Közel 20 éve felelöse a posztgraduális könyvtári tanulmányok oktatásának. Tagja volt az IFLA WLIC 2017-es wroclawi konferenciája nemzeti szervezőbizottságának. 